\title{
Taxonomic relevance of petiole anatomical and micro- morphological characteristics of Clematis L. (Ranunculaceae) taxa from South Korea
}

\author{
Beom Kyun Park ${ }^{1}$, Dong Chan Son ${ }^{1}$, Balkrishna Ghimire ${ }^{\text {Corresp. } 1}$ \\ ${ }^{1}$ Division of Forest Biodiversity, Korea National Arboretum, Pocheon, South Korea \\ Corresponding Author: Balkrishna Ghimire \\ Email address: ghimireab@korea.kr
}

We assessed the micro-morphological and anatomical structures of the petioles of 19 Clematis taxa from South Korea. The petiole surface features were observed with the help of stereomicroscopy and scanning electron microscopy, and the anatomical features are studied via microtomy and light microscopy. The results of this study showed that the presence/absence and abundance of trichomes, petiole cross-section outlines, upper surface wings and grooves, and the number of vascular bundles were useful for species discrimination in Clematis. Among the studied taxa, $C$. hexapetala was the only species with a glabrous petiole surface. Two types of trichomes were observed in the other 18 taxa: long, non-glandular and flagelliform trichomes and short, glandular capitate trichomes. We found four to six major vascular bundles and a maximum of eight interfascicular vascular bundles (C. heracleifolia and C. urticifolia) in the 19 taxa. A cluster analysis based on UPGMA identified six clusters with 18 nodes. Although the number of taxa investigated was limited, taxa from the sections Tubulosae, Viorna, and Astragene clustered with each other in the UPGMA phenogram due to the overall similarity of petiole features. Based on this observation, we can conclude that most of the petiole features are limited to the species level, and thus, the data obtained could be used as descriptive and/or diagnostic features for particular taxa, which may be useful for the investigation of problematic taxa in the genus. 
1 Taxonomic relevance of petiole anatomical and micro-morphological

2 characteristics of Clematis L. (Ranunculaceae) taxa from South Korea

3

4

5 Beom Kyun Park, Dong Chan Son, Balkrishna Ghimire*

6 Division of Forest Biodiversity, Korea National Arboretum, Pocheon 11186, South Korea

$7 \quad *$ Corresponding author: ghimire2ab@gmail.com

8 Number of figures: 8

9 Number of tables: 2

10 Supplementary file: 1

11

12

13

14

15

16

17

18

19

20

21

22

23

24

25 


\section{ABSTRACT}

We assessed the micro-morphological and anatomical structures of the petioles of 19 Clematis taxa from South Korea. The petiole surface features were observed with the help of stereomicroscopy and scanning electron microscopy, and the anatomical features are studied via microtomy and light microscopy. The results of this study showed that the presence/absence and abundance of trichomes, petiole cross-section outlines, upper surface wings and grooves, and the number of vascular bundles were useful for species discrimination in Clematis. Among the studied taxa, C. hexapetala was the only species with a glabrous petiole surface. Two types of trichomes were observed in the other 18 taxa: long, non-glandular and flagelliform trichomes and short, glandular capitate trichomes. We found four to six major vascular bundles and a maximum of eight interfascicular vascular bundles (C. heracleifolia and C. urticifolia) in the 19 taxa. A cluster analysis based on UPGMA identified six clusters with 18 nodes. Although the number of taxa investigated was limited, taxa from the sections Tubulosae, Viorna, and Astragene clustered with each other in the UPGMA phenogram due to the overall similarity of petiole features. Based on this observation, we can conclude that most of the petiole features are limited to the species level, and thus, the data obtained could be used as descriptive and/or diagnostic features for particular taxa, which may be useful for the investigation of problematic taxa in the genus.

Keywords: Petiole morphology, Clematis, Trichomes, Vascular bundle, Infrageneric relationship, Taxonomy

\section{INTRODUCTION}

Ranunculaceae is one of the larger families of eudicots, comprising nearly 2500 species within 50-60 genera (Tamura, 1993; Hoot et al., 2012; Wang et al., 2013). The family has been classified under the early branching order of eudicot Ranunculales $(A P G I V, 2016)$. Ranunculaceae are distributed across the world and exhibit their greatest diversity in the temperate and cold regions of the Northern and Southern Hemispheres (Tamura, 1993). A number of classification models that consider morphological characters, molecular sequencing, and a combinations of both morphological and molecular data have been proposed for this family (Hutchinson, 1923; Janchen, 1949; Johansson \& Jansen, 1993; Tamura, 1995; Hoot, 1995; Jensen et al., 1995; Ro et al., 1997; Wang et al., 2009, 2013; Emadzade et al., 2010; Hoot et al., 2012; Wang et al., 2014; Zhai et al., 2019). In addition to the various morphological criteria, the basic chromosome numbers and types of chromosomes have become reliable references that are compatible with the molecular phylogeny of Ranunculaceae (Gregory, 1941; Tamura, 1987; Ro et al., 1997; Wang et 
al., 2009; Heywood et al., 2007).

Within Ranunculaceae, Clematis L. is classified under the tribe Anemoneae DC. in the subfamily Ranunculoideae Hutch. (Tamura, 1995). Clematis is one of the largest genera in the family, which comprises approximately 280-350 cosmopolitan species (Tamura, 1987, 1995; Wang \& Li, 2005). In Korea, Nakai (1952) reported 21 species and 14 varieties of Clematis in a synoptical sketch of Korean flora, but Lee (1967) later identified 16 species, 11 varieties, and five forma in the genus. In the book New Flora of Korea, Lee (2007) described 18 taxa, including C. taeguensis Y. Lee, which was first described by Lee (1982). The Korea National Arboretum (2017) recently listed 17 species and five varieties of Clematis in the Checklist of Vascular Plants in Korea, whereas Kim (2017) described 13 species and seven varieties within the genus in The Flora of Korea. After a careful review of Lee (2007), Chang et al. (2011), the Korea National Arboretum (2017), and Kim (2017),we included 16 species and three varieties in this study.

Due to the vast morphological disparity among its species, Clematis has been a subject of investigation since the early $19^{\text {th }}$ century and has been subjected to several infrageneric revisions. Several systematic studies based on the anatomy of different parts, palynology, and cytology of Clematis have been carried out (Tobe, 1974, 1980a, 1980b, 1980c, 1980d; Essig, 1991; Zhang, 1991; Yano, 1993; Yang \& Moor, 1999; Shi \& Li, 2003; Xie \& Li, 2012; Ghimire et al., 2020). The morphological characters that have been extensively studied and considered in the infrageneric classifications of Clematis include the habit, seed germination, seedling phyllotaxy, leaf structure, inflorescence vertical structure, floral morphology, and pollen and achene morphology (see Wang \& $L i, 2005$ ).

The importance of the nodal and petiolar anatomy in intergeneric and familial taxonomy has been extensively studied (Howard, 1962, 1979; Schofield, 1968; Dickison, 1969, 1980; Datta \& Dasgupta, 1979). The middle portion of the petiole is considered the most stable zone, from which even a single section can be taken for comparative purposes (Metcalfe \& Chalk, 1979). In addition, the complex vascular systems of the petiole provide a range of diagnostic structures that can be useful for taxonomic treatment at any rank (Solereder, 1908; Metcalfe \& Chalk, 1979; Ashton, 1982; Dehgan, 1982; Rojo, 1987; Pardi et al., 1991; Kamel \& Loutfy, 2001; Kocsis \& Borhidi, 2003; Noraini et al., 2016, 2017). Within Ranunculaceae, few taxonomic-related investigations based on the anatomy of petioles, nodes, and stems have been carried out (Worsdell, 1908; Tamura, 1962; Oh, 1971; Kavathekar \& Pilli, 1976; Tobe, 1979, 1980; Kökdil et al., 2006; Gostin, 2011; Novikoff \& Mitka, 2015). Unfortunately, studies pertaining to the petiole morphology and anatomy of Clematis, as one of the most morphologically diverse and taxonomically complicated genera within Ranunculaceae, are very rare in the literature. In an anatomical study of Clematis in Korea, only Oh (1971) provided remarks on the petiole anatomy of nine Korean species. 
In this study, we provide a comprehensive investigation of the petiole micromorphology and anatomy of 19 Clematis taxa distributed in Korea. The primary objective of this study was to investigate the petiole micromorphological and anatomical structure of the included taxa in detail and to evaluate the implications of petiolar characters for species delimitation. We attempted to compare our results with those obtained for previously studied species and summarized them to reach taxonomic conclusions.

\section{MATERIALS AND METHODS}

\section{Plant materials}

The names of the investigated species and their voucher numbers are provided in Table 1. Formal identification of the plant taxa was carried out by a group of plant taxonomists, including Dr. Dong Chan Son (one of the authors) in the Korea National Arboretum. The voucher specimens were deposited in the herbarium of the Korea National Arboretum (KH). Data were collected as previously described in Ghimire et al. (2020)

\section{Stereo and scanning electron microscopy}

The petiole morphology, including the indumentum, trichome type and abundance, and upper surface groove was observed under a stereomicroscope and a scanning electron microscope (SEM). A Leica MZ16 FA microscope (Leica Microsystems GmbH, Wetzlar, Germany) was used for the observations and digital images of the best-represented part of the petiole were taken with a Leica DFC420 C multifocal camera attached to the microscope. Before SEM imaging, petiole pieces were immersed in 100\% ethanol and sputter-coated with gold in a KIC-IA COXEM Ion-Coater (COXEM. Co., Ltd., Daejeon, Korea). SEM imaging was carried out with a COXEM EM-30 PLUS+ table scanning electron microscope (COXEM) at $20 \mathrm{kV}$ at the seed testing laboratory of the Korea National Arboretum.

\section{Microtome and light microscopy}

At least three petioles of each taxon were subjected to microtome sectioning according to the following procedure used in Ghimire et al, (2020). Freshly collected leaf petioles were fixed in formalin, acetic acid, and 50\% ethyl alcohol (FAA) at a ratio of 5:5:90 for one week and preserved in 50\% ethyl alcohol. During the experiment, the preserved petioles were cut into small pieces (approximately $2 \mathrm{~mm}$ ) and dehydrated with an ethanol series $(50,70,80,90,95$ and 100\%). After complete dehydration, the petiole pieces were infiltrated with ethanol/Technovit mixtures (3:1, 1:1, 1:3, and 100\% Technovit) and then embedded in Technovit 7100 resin. The embedded materials were cut into serial sections of 4-6 $\mu \mathrm{m}$ thickness using a Leica RM2255 rotary microtome (Leica Microsystems GmbH, Wetzlar, Germany) with 
123 disposable blades and attached to a glass slide. The slides were dried using an electric slide warmer for 12

124 h. The dried slides were stained with $0.1 \%$ toluidine blue ' $O$ ' for $60-90 \mathrm{~s}$, rinsed with water and dried 125 again with the slide warmer for at least $6 \mathrm{~h}$ to remove any remaining water (Johansen, 1940). The stained 126 slides were then mounted with Entellan (Merck Co., Darmstadt, Germany) and later examined under a 127 Leica DM3000 LED (Leica Microsystem, Wetzlar, Germany). Photomicrographs were taken with a 128 scientific CMOS camera. Multiple image alignment was performed using Photoshop CS for Windows 1292010.

\section{Morphometry and data analysis}

131 Thirteen quantitative characters were categorized and coded binary and/or multistate. The character states 132 and their codes are provided in Supplementary File S1. Principal component analysis (PCA) and cluster

133 analysis using the unweighted pair group (UPGMA) clustering method using the Gower general similarity 134 coefficient were carried out with MultiVariate Statistical Package 3.1 software (MVSP Version 3.1)

135 (Kovach, 1999).

\section{RESULTS}

137 The morphological and anatomical characters of Clematis petioles observed in this study include the 138 petiole indumentum, trichome type and abundance, petiole outline in cross-section (CS), upper surface 139 wings and groove of the petiole, sclerenchyma region, and vascular bundles. All the characters are 140 summarized in Table 2. Selected images of the petioles are provided in Figures 1-6. The morphological 141 and anatomical features of the petiole are comprehensively described below.

\section{Petiole surface and trichomes}

143 The petiole surface of the studied species is pubescent except in Clematis hexapetala, which has an 144 almost glabrous surface (a few trichomes occur in the region from which leaflets arise) (Table 2, Fig. 1AS). Clematis taeguensis and C. serratifolia have subglabrous petiole surfaces, and only a few trichomes occur on the petioles of these species. Two types of trichomes are observed on the petiole: long, nonglandular, flagelliform trichomes and short, glandular, capitate trichomes (Figs. 1A-S, 2A-J). Glandular trichomes are usually distributed in the upper surface groove. In some species such as C. terniflora, $C$. terniflora var. mandshurica, C. brachyura, C. fusca var. fusca, and C. fusca var. violacea, non-glandular trichomes are concentrated only on the upper surface groove. The pubescent species can be categorized as 'villous', which are covered with long, soft, and dense hairs (i.e., C. apiifolia, C. brevicaudata, C. 
154

155

156

157

158

159

160

161

162

163

164

165

166

167

168

169

170

171

172

173

174

175

176

177

178

179

180

181

182

183

184

mandshurica, C. patens, C. brachyuran, C. fusca var. fusca, C. fusca var. flabellata, C. fusca var. violacea, C. koreana, and C. ochotensis). The non-glandular trichomes are either unicate (C. apiifolia, $C$. brevicaudata, C. heracleifolia, C. urticifolia, and C. takedana) or flabelliform (all other species except $C$. hexapetala). Based on the trichome density per unit area, the trichome abundance was categorized as high, medium, or low.

\section{Petiole outline and upper surface groove}

The studied species show considerable variation in their CS petiole outline (Table 2). The species can be divided into three categories based on the shape of their petioles in CS: pentagonal petioles (seven species), U-shaped petioles (nine species), and U-shaped or semi-circular petioles (only C. terniflora) (shown in Figs. 3, 4, 5, and 6). Clematis hexapetala and C. serratifolia exhibit both pentagonal and semicircular petioles in CS. Out of the 19 taxa, 13 taxa exhibited two noticeable upper or dorsal surface wings, while six species did not have noticeable wings. Based on the shape of the upper surface groove, the petioles can be categorized as flattened (three species), sub-flattened (11 species), U-shaped (three species), or V-shaped (three species). The formation of the upper surface groove is due primarily to the dorsal surface wings, although some species with inconspicuous wings have a slight groove in the petiole (C. brevicaudata, C. trichotoma, and C. heracleifolia).

\section{Petiole epidermis and cortex}

The epidermis is single-layered and cutinized in all species (Figs. 3, 4, 5, and 6). The cells are small, rounded, cuboidal, narrow, or slightly elongated. In some places, the continuation of the epidermis is interrupted by the presence of stomata. Stomata are important regulators of gas and water exchange in plants and are usually found in the leaves. They can be found in the stem and petiole but are less prominent in comparison to the leaf. The epidermis is underlain by the cortex, which is 3-5 cells thick.

The cortical cells are loosely arranged and parenchymatous with abundant air spaces and are rounded, ovoid, elongated, or irregular in shape. The cortex is collenchymatous above the phloem patches, where the cells are thick-walled and closely packed.

\section{Vascular bundles}

The vascular bundles are of the open, conjoint, collateral type. There is remarkable variation in the number of vascular bundles (ranging from 5 to 14) among Clematis species. The 19 taxa have four to six major vascular bundles and a maximum of eight interfascicular vascular bundles $(C$. heracleifolia and $C$. urticifolia). Twelve species have five major vascular bundles, six species have six, and only C. patens has four (Table 2). The major vascular bundles are ovoid with the phloem oriented towards the cortex and the 
185

186

187

188

189

190

191

192

193

194

195

196

197

198

199

200

201

202

203

204

205

206

207

208

209

210

211

212

213

214

215

216

xylem oriented towards the pith. The xylem and phloem are separated by 2-4 layers of cambial cells. Each major vascular bundle is overlain with a cluster of thick-walled fibrous cells, i.e., the phloem fibre cap.

The quantity of phloem fibres within the studied species is variable. Based on its height in cell layers, the phloem cap is categorized as large (more than ten cells high), medium (five to ten cells high), or small (less than five cells high). Three species C. terniflora, C. fusca var. fusca, and C. koreana, have small fibre caps, while seven and nine species have medium and large fibre caps, respectively. There is a permanent sclerenchymatous strand between the adjacent vascular bundles in all species.

The petiole of each species has a large region of the ground tissue, i.e., the pith. The cells in the pith are thin-walled, rounded, ovoid, or angular and parenchymatous and are comparatively larger than those in the cortex (Figures 3, 4, 5, and 6).

\section{Statistical analysis}

The similarities among the species based on the 13 petiole features were revealed using PCA and cluster analysis. The first three components of the PCA explained $74.01 \%$ of the total variation in the analysed data. The first axis of the first complete set explained $42.66 \%$ of the total variation and showed strong positive loadings for the trichome abundance and the number of vascular bundles (TA, IV, VB, and VG) (Fig. 7). The second axis explained $16.86 \%$ of the total variation and showed strong positive loadings for the trichome type and upper surface groove (TT and UG) and strong negative loadings for phloem the fibre cap height and interfascicular sclerenchyma (PF and SC). The cluster analysis based on UPGMA using the Gower similarity coefficient identified six clusters with 18 nodes (Fig. 8). Clematis fusca var. fusca and C. fusca var. violacea, representing the first node in the sixth cluster of the phenogram, showed 93.6\% similarity in petiole features, whereas $C$. hexapetala and C. serratifolia, representing the $18^{\text {th }}$ node in the first cluster in the phenogram, shared only $52.7 \%$ similarity in petiole features with the rest of the species.

\section{DISCUSSION}

The genus Clematis is morphologically diverse in terms of leaf phyllotaxy, types of compound leaves, and leaflet number. The anatomy of the petiole, therefore, is expected to be equally diverse. Previously, Oh (1971) found variation in the number of vascular bundles in the petiole of some Clematis species. Thus, reasonable diversity in petiole anatomical features, including variation in the number of vascular bundles, is certainly useful for the taxonomic treatment of the genus. The overall anatomical organization of the petioles in the investigated species was comparable to that described in Oh (1971). In addition, this study provides a comprehensive anatomical description of the petioles of all Korean Clematis species and a discussion of their taxonomic relevance within the genus, which have not been included in previous 
217 studies.

218 The results of this study showed that Clematis species can be differentiated based on the petiole 219 indumentum. The presence/absence and/or type of trichomes in the petiole have also been used for 220 species differentiation in other taxa (Solereder, 1908; Metclafe \& Chalk, 1979; Noraini et al., 2017).

221 Among the 19 species investigated, Clematis hexapetala is the only species with glabrous petioles

222 (although sparsely distributed trichomes can be observed at the base of the leaflets), whereas $C$.

223 taeguensis and C. serratifolia have subglabrous or sparsely pubescent indumentum. The remaining 224 species have sparsely or thickly pubescent petioles. In sparsely pubescent taxa such as $C$. terniflora, $C$.

225 terniflora var. mandshurica, C. fusca var. fusca, and C. fusca var. violacea, the trichomes are restricted to 226 mainly the upper groove region. Additionally, the stem of these taxa is either subglabrous or puberulous 227 only at nodes (Wang \& Bartholomew, 2001; Kim, 2017). On the other hand, species such as C. apiifolia,

228 C. heracleifolia, C. urticifolia, and C. takedana, which have thickly pubescent petioles, also have heavily 229 pubescent stems and branches (Wang \& Bartholomew, 2001; Kadota, 2006; Moon et al., 2013; Kim,

230 2017). This indicates that the trichomes in the petiole are generally continuous with those on the stem in 231 the Clematis species.

232 Most of the species have both types of trichomes, although glandular trichomes are very scarce 233 and restricted to the upper surface groove of the petiole. We observed both glandular capitate and simple 234 non-glandular trichomes on the leaf surface of most of the investigated Clematis species (Ghimire et al. 235 unpublished report). Glandular pubescence on the stem, petiole and leaf of C. gattingeri Small has been 236 reported in a few older studies (Svenson, 1941; Dennis, 1978). Petiole features that are considered to be 237 useful for taxonomic discrimination in various taxa (Solereder, 1908; Metcalfe \& Chalk, 1979; Dehgan, 238 1982; Rojo, 1987; Pardi et al., 1991; Kamel \& Loutfy, 2001; Kocsis \& Borhidi, 2003; Noraini et al., 239 2016, 2017) are generally neglected in morphological studies of Clematis because no recent reports have 240 considered the systematic utility of such pubescence for the infra-generic classifications of this genus 241 (Tamura, 1995; Wang \& Li, 2005; Lehtonen et al., 2016; Wang \& Bartholomew, 2001; Kadota, 2006; 242 Kim, 2017). In a taxonomic study of C. gattingeri, Dennis (1978) confirmed the presence of glandular 243 pubescence on the stem, petiole, and leaf, which had never been observed in other species of subsection 244 Viornae. The recognition of $C$. gattingeri as a species has been based primarily on the glandular 245 pubescence and small flower size of Gattinger's specimens. The results from this study also revealed that 246 the petiole indumentum and types of trichomes appear to have taxonomic value for species delimitation in 247 Clematis.

248 In addition to the surface indumentum, some other petiole features that can contribute to the 249 identification of a particular species in Clematis include the petiole outline in CS, the upper surface 250 groove and wings, and the phloem fibre cap. Of these features, the petiole outline and upper surface 
251

252

253

254

255

256

257

258

259

260

261

262

263

264

265

266

267

268

269

270

271

272

273

274

275

276

277

278

279

280

281

282

283

284

groove and wings have already been proven to be useful in the taxonomic discrimination of species in some eudicot genera (Kocsis \& Borhidi, 2003; Noraini et al., 2017; Abeysinghe \& Scharaschkin, 2019). Oh (1971) reported pentagonal and/or horseshoe or rounded horseshoe-shaped petioles in nine Clematis species, and the results of this study corroborated those reports. We observed that the petiole of Clematis in CS is dorsiventral, pentagonal with five visibly and/or weakly represented ridges or semicircular and ridgeless. Clematis hexapetala and C. serratifolia appear to have both pentagonal and U-shaped petioles, whereas some petioles of $C$. terniflora are semi-circular. Species with pentagonal petioles have conspicuous upper surface wings that form an upper surface groove, while some of the species with Ushaped petioles have inconspicuous upper surface wings. Species with inconspicuous wings such as $C$. brevicaudata, C. trichotoma, C. heracleifolia, and C. terniflora, still form a slight upper surface groove. Of the three taxa C. fusca var. fusca, C. fusca var. flabellata, and C. fusca var. violacea, the first has a pentagonal petiole, while the latter two have U-shaped petioles with noticeable upper wings. Interestingly, these three taxa showed dissimilar upper surface groove characteristics: $C$. fusca var. violacea has a subflattened groove, whereas C. fusca var. fusca and C. fusca var. flabellata have a U-shaped groove. Although reports on such upper wing extensions and adaxial grooves on the petiole are lacking in the literature, our study suggests the possibility of using these features for species identification in Clematis.

In petiole anatomy, the vascular system of the petiole has received the most attention (Kocsis \& Borhidi, 2003; Noraini et al., 2016; 2017; Abeysinghe \& Scharaschkin, 2019). According to Hare (1942), various arrangements of vascular bundles in the petiole can be used as diagnostic characteristics in some taxonomic groups. Howard $(1962,1974)$ suggested that the vascular structure of the petiole is most useful at the generic level and sometimes at the family level, although the intensity of the taxonomic value may vary from one taxonomic group to another. The Clematis petiole showed remarkable consistency in the arrangement of the vascular system, although the studied species differ from each other by the number of major and interfascicular vascular bundles. There are typically five major vascular bundles, which possibly correspond to the five ridges of the petiole; however, C. patens, with exclusively U-shaped petioles, has no ridges, wings, or upper surface grooves, and has only four major vascular bundles. In some taxa, such as C. apiifolia, C. taeguensis, C. hexapetala, C. terniflora var. mandshurica, C. heracleifolia, and C. takedana, the vascular bundle in the upper groove regions develops in the same way as the vascular bundles in the edges, resulting in a total of six major vascular bundles in these taxa.

Regarding the number of vascular bundles, the results of this study are almost congruent with those of Oh (1971) for C. apiifolia, C. trichotoma, and C. koreana but are slightly different for C. brachyura and $C$. patens, in which he described six major and four interfascicular vascular bundles and six major vascular bundles, respectively. Instead, we observed five major and four interfascicular vascular bundles in C. brachyura and four major and one or two interfascicular bundles in C. patens. We observed 
285

286

287

288

289

290

291

292

293

294

295

296

297

298

299

300

301

302

303

304

305

306

307

308

309

310

311

312

313

314

315

316

317

318

variation in the number and position of interfascicular bundles even in the different samples of the same species, including in C. patens, thus, this feature may have only slight taxonomic value for discriminating among Clematis species. On the other hand, the number and position of the major vascular bundles, which showed remarkable consistency among the investigated samples of all species, may have significant taxonomic value for species discrimination within the genus. At this point, our results suggest that the pre-existing data presented by $O h$ (1971) on the number of vascular bundles specifically, the number of major bundles in the petioles of Clematis species should be corrected.

The cluster analysis based on 13 petiole features generated at least six clusters. Of these, Clematis serratifolia and $C$. hexapetala formed the first cluster, which was separate from the rest of the species (Fig. 8). The sixth cluster was the largest comprising seven taxa: C. calcicola, C. ochotensis, C. fusca var. fusca, C. fusca var. violacea, C. fusca var. flabellata, C. koreana, and C. brachyura. According to Johnson (2001) and Wang \& Li (2005), these seven taxa belong to the sections Viorna (C. fusca var. fusca, C. fusca var. violacea, C. fusca var. flabellata), Atragene (C. ochotensis, C. calcicola, and C. koreana), and Pterocarpa (C. brachyura). In a recent phylogenetic classification of the genus, $C$. fusca var. fusca, C. fusca var. violacea, and C. fusca var. flabellata were classified under clade L; C. ochotensis, C. calcicola, and C. koreana were classified under clade H: and C. brachyura was classified under clade K (Lehtonen et al., 2016). Additionally, C. urticifolia, C. takedana, and C. heracleifolia, which made up the third cluster in the UPGMA phenogram in this study, belong to section Tubulosae in the Johnson (2001) and Wang \& Li (2005) classification and to clade C in Lehtonen et al. (2016). According to infrageneric classifications by Tamura (1995), Wang \& Li (2005) and Xie et al. (2011), C. brachyura is considered to be closer to section Flammula (C. taeguensis, C. hexapetala, C. terniflora var.

mandshurica, and C. terniflora). However, in this study, it remained connected to the Viorna and Atragene sections. In fact, this uncertainty is a common and typical interpretation for this large genus, as previous morphological and molecular studies also found a similar tendency (Grey-Wilson, 2000; Wang \& Li, 2005; Miikeda et al., 2006; Xie et al., 2011; Xie \& Li, 2012; Lehtonen et al., 2016; Ghimire et al., 2020).

According to PCA, the close affinity of the taxa from section Tubulosae is well retained by their proximity in axis 1 (Fig. 7). Previous studies have suggested that neither molecular analyses nor morphological data strongly support the infrageneric classification of Clematis. We agree with most authors that performing infrageneric classification of Clematis based on morphological characters is extremely difficult. In our analysis, out of the three taxa from section Viorna, C. fusca var. flabellata was grouped with C. koreana (section Atragene) and C. brachurya (section Pterocarpa), whereas C. fusca var. fusca and C. fusca var. violacea remained together in a separate sub-cluster. The PCA biplot also inferred similar relationships among these three subspecific taxa, with C. fusca var. flabellata was 
319

320

321

322

323

324

325

326

327

328

329

330

331

332

333

334

335

336

337

338

339

340

341

342

343

344

345

346

\section{7}

348

349

350

positioned on the positive side of axis 1, while C. fusca var. fusca and C. fusca var. violacea remained closer on the negative side of axis 1 . The petioles of $C$. fusca var. flabellata differ from those of $C$. fusca var. fusca and C. fusca var. violacea in terms of the trichome abundance, phloem fibre cap height, and number of vascular bundles. In terms of morphology, C. fusca var. flabellata is an erect herb with ternate leaves, whereas $C$. fusca and $C$. fusca var. violacea are woody vines with pinnately foliate leaves. In addition, of the three species in section Clematis, C. trichotoma and C. brevicaudata formed a sub-cluster with C. patens (section Viticella), while C. apiifolia allied with C. terniflora (section Flammula) in another sub-cluster. The PCA showed a slightly different pattern, as $C$. apiifolia remained closer to $C$. serraatifolia and $C$. patens on the negative side of both axes, whereas $C$. brevicaudata allied with $C$. taeguensis and C. terniflora var. mandshurica on the positive side of axis 1 and the negative side of axis 2. Morphologically, the petiole of C. apiifolia differs from those of the other two species in its trichome abundance, outline in CS, phloem fibre cap, intrafascicular sclerenchyma, and number of vascular bundles. Notably,petiole features alone can be more useful for species delimitation than for distinguishing infrageneric relationships and thus are not indicative of infrageneric classifications. Similar explanations were provided by Ghimire et al. (2020) and Xie \& Li (2012) based on the achene morphology and pollen morphology of Clematis, respectively.

In conclusion, the presence/absence and abundance of trichomes, petiole outline in CS, upper surface wings and groove, and number of vascular bundles were determined to be useful for species discrimination in Korean Clematis. The results of this study also indicated that taxa from the sections Tubulosae, Viorna, and Atragene could be grouped based on the overall similarity of their petiole features. Moreover, we found that many of the petiole characters such as the abundance of trichomes, upper surface wings and grooves, and number of vascular bundles, that were neglected in taxonomic and systematic considerations within and among Clematis taxa can be useful for species delimitation. We do not consider these petiole morphological data to be strong enough to provide useful information on infrageneric relationships with the Clematis genus; however, our results provide new and interesting insights into these data, which can be used as a source of descriptive and/or diagnostic features for particular taxa in the genus.

\section{ADDITIONAL INFORMATION AND DECLARATION}

\section{Author Contributions}

- BKP conceived the study, performed the experiment, analysed the data, and wrote and reviewed drafts of the manuscript. 
351

352

353

354

355

356

357

358

359

360

361

362

363

364

365

366

367

368

369

370

371

372

373

374

375

376

377

378

379

380

381

382

383

- BG and DCS conceived the study and designed the experiment, analysed the data, and wrote and reviewed the draft.

\section{References}

Abeysinghe PD, Scharaschkin T. 2019. Taxonomic value of the petiole anatomy in the genus Cinnamomum (Lauraceae) found in Sri Lanka. Ruhuna Journal of Science 10:1-17. DOI: $\underline{\text { http://doi.org/10.4038/rjs.v10i1.47 }}$

APG IV. 2016. An update of the angiosperm phylogeny group classification for orders and families of flowering plants. Botanical Journal of the Linnean Society 181:1-20. DOI: http://doi.org/10.1111/boj.12385

Ashton PS. 1982. Dipterocarpaceae. In Van Steenis C. G. G. J. (ed.). Flora Malesiana, Series 1, Spermatophyta (Seed Plant), vol. 9, Martinus Nijhoff Publishers, Dordrecht, Pp.237-552.

Chang CS, Kim H, Chang KS. 2011. Illustrated encyclopedia of fauna \& flora of Korea. Vil. 43. Woody Plants. Ministry of Education Science and Technology, Seoul, 511pp.

Datta PC, Dasgupta A. 1979. Comparison of vegetative anatomy of Piperales. ILL. Vascular supplies to leaves. Acta Botanioca Indica 7:39-46.

Dehgan B. 1982. Comparative anatomy of the petiole and infrageneric relationships in Jatropha (Euphorbiaceae). American Journal of Botany 69:1283-1295.

Dickison WC. 1969. Comparative morphological studies in Dilleniaceae, IV. Anatomy of the node and vascularization of the leaf. Journal of Arnold Arboretum 50:384-410. https://www.jstor.org/stable/43781663

Dickison WC. 1980. Diverse nodal anatomy of the Cunoniacae. American Journal of Botany 67:975-981. https://doi.org/10.2307/2442440

Essig F. 1991. Seedling morphology in Clematis (Ranunculaceae) and its taxonomic implications. Sida 14:377-390. https://www.jstor.org/stable/41966899

Emadzade K, Lehnebach C, Lockhart P, Hörandl E. 2010. A molecular phylogeny, morphology and classification of genera of Ranunculeae (Ranunculaceae). Taxon 59: 809-828. https://www.jstor.org/stable/25677670

Ghimire B, Park BK, Son DC, Oh SH. 2020. Achene morphology and anatomy of Clematis L. (Ranunculaceae) in Korea and its taxonomic implications. Plants 9:1279. https://doi.org/10.3390/plants9101279

Gostin IN. 2011. Anatomical and micromorphological peculiarities of Adonis vernalis L. (Ranunculaceae). Pakistan Journal of B3:811-820. http://www.pakbs.org/pjbot/PDFs/43(2)/PJB43(2)0811.pdf 
384

385

386

387

388

389

390

391

392

393

394

395

396

397

398

399

400

401

402

403

404

405

406

407

408

409

410

411

412

413

414

415

416

Gregory WC. 1941. Phylogenetic and cytological studies in the Ranunculaceae. Transaction of the American Philosophical Society 31:443-521. https://doi.org/10.2307/1005611

Grey-Wilson C. 2000. Clematis the genus. Portland, Oregon: Timber Press.

Heywood VH, Brummitt RK, Culham A, Seberg O. 2007. Flowering plant families of the world. Royal Botanical Garden, Kew 424 pp.

Hoot SB. 1995. Phylogeny of the Ranunculaceae based on preliminary $a t p \mathrm{~B}, r b c \mathrm{~L}$ and $18 \mathrm{~S}$ nuclear ribosomal DNA sequence data. Plant Systematics and Evolution [Supplement] 9:241-251. https://doi.org/10.1007/978-3-7091-6612-3_24

Hoot SB, Meyer KM, Manning JC. 2012. Phylogeny and reclassification of Anemone (Ranunculaceae), with an emphasis on austral species. Systematic Botany 37: 139-152. https://doi.org/10.1600/036364412X616729

Hare CL. 1942. On the taxonomic value of the anatomical structure of the vegetative organs of the dicotyledons: The anatomy of the petiole and its taxonomic value. Proceedings of the Linnean Society of London 555(3):223-229. https://doi.org/10.1111/j.1095-8312.1944.tb00359.x

Howard RA. 1962. The vascular structure of the petiole as a taxonomic character. In: Garnaud JC, ed. Advances in horticultural science and their applications, Vol. III. Pergamon Press, New York, 7-13.

Howard RA. 1974. The stem-node-leaf continuum of the dicotyledoneae. Journal of Arnold Arboretum 55:125-173. https://www.jstor.org/stable/43781932

Howard RA. 1979. The petiole. In Metcalfe CR \& Chalk L, eds. Anatomy of the Dicotyledons, ed. 2, Oxford, Clarendon Press 1:88-96.

Hutchinson J. 1923. Contribution towards a phylogenetic classification of flowering plants 1. Kew Bulletin 1920:65-89. https://doi.org/10.2307/4118622

Janchen E. 1949. Die systematische Gliederung der Ranunculaceen und Berberidaceen (Denkschriften der Österreichischen Akademie der Wissenschaften). Math.-Na-turwiss. Kl., Denkschr. Springer Vienna 82.

Jensen U, Hoot SB, Johansson JT, Kosuge K. 1995. Systematics and phylogeny of the Ranunculaceae; a revised family concept on the basis of molecular data. Plant Systematics and Evolution Supplement 9:273-280. https://doi.org/10.1007/978-3-7091-6612-3_27

Johansson JT, Jansen RK. 1993. Chloroplast DNA variation and phylogeny of the Ranunculaceae. Plant Systematics and Evolution 187:29-49. https://doi.org/10.1007/BF00994090

Johnson M. 1997. Släktet Klematis. Södertälje: M. Johnsons Plantskola AB.

Kadota Y. 2006. Clematis L. In Iwatsuki K, Boufford DE \& Ohba H, eds. Flora of Japan IIa Angiospermae Dicotyledoneae Archichlamydeae(a). Tokyo: Kodansha Ltd. 298-308. 
Kamel EA, Loufty MHA. 2001. The significance of cuticular features, petiole anatomy and SDS-PAGE in the taxonomy of the Lauraceae. Pakistan Journal of Biological Sciences 4:1094-1100. DOI: $10.3923 / p j b s .2001 .1094 .1100$

Kavathekár KY, Pillai A. 1976. Studies on the developmental anatomy of Ranales. II - Nodal anatomy of certain members of Annonaceae, Magnoliaceae, Menispermaceae and Ranunculaceae. Flora 165:481-488. https://doi.org/10.1016/S0367-2530(17)31886-8

Kim JS. 2017. Clematis L. Flora of Korea: Volume 2a, Magnoliidae, 69-76p.

Kocsis M, Borhidi A. 2003. Petiole anatomy of some Rubiaceae genera. Acta Botanica Hungarica 45:345-353. https://doi.org/10.1556/abot.45.2003.3-4.9

Kökdil G, Ilcim A, Özbilgin B, Uygun C. 2006. Morphology and stem anatomy of some species of genus Nigella L. in Turkey. Ankara Üniversitesi Eczacılı Fakültesi Dergisi 35:19-41. DOI:10.1501/ECZFAK 00000000049

Korea National Arboretum. 2017. Checklist of Vascular Plants in Korea. Korea National Arboretum. Pocheon, 1,000pp.

Kovach WL. 1999. MVSP, a multivariate statistical package for Windows, Version 3.1. Pentraeth, Wales: Kovach Computing Services.

Lee CB. 1967. Illustrated woody plants of Korea. Forest Experiment station, 1-384.

Lee YN. 1982. New taxa of Korean flora (4). Korean Journal of Botany 25: 175-180. https://doi.org/10.11110/kjpt.1992.22.1.007

Lee YN. 2007. New flora of Korea Volume I. Kyo-Hak Publishing Co. Ltd. Seoul, Korea, 2007.

Lehtonen S, Christenhusz MJM, Falck D. 2016. Sensitive phylogenetics of Clematis and its position in Ranunculaceae. Botanical Journal of Linnean Society 182:825-867. https://doi.org/10.1111/boj.12477

Metcalfe CR, Chalk L. 1979. Anatomy of the Dicotyledons. Vol 1. Oxford: Clarendron Press.

Miikeda O, Kita K, Handa T, Yukawa T. 2006. Phylogenetic relationships of Clematis (Ranunculaceae) based on chloroplast and nuclear DNA sequences. Botanical Journal of Linnean Society 152:153-168. https://doi.org/10.1111/j.1095-8339.2006.00551.x

Moon AR, Han JE, Lee BY, Park JM, Jang C. 2013. An unrecorded species of genus Clematis (Ranunculaceae) from Korea. Journal of Asia Pacific Biodiversity 6:415-418. https://doi.org/10.7229/jkn.2013.6.4.00415

Nakai T. 1952. Synoptical sketch of the Korean Flora. Bulletin of the National Science Museum [Tokyo, Japan] 31: 1-152. 
449

450

451

452

453

454

455

456

457

458

459

460

461

462

463

464

465

466

467

468

469

470

471

472

473

474

475

476

477

478

479

480

481

Noraini T, Ruzi AR, Ismail BS, Ummu BH, Salwa S, Azij A. 2016. Petiole vascular bundles and its taxonomic value in the Tribe Dipterocarpeae (Dipterocarpaceae). Sains Malaysiana 45:247-253.

Novikoff AV, Mitka J. 2015. Anatomy of stem-node-leaf continuum in Aconitum (Ranunculaceae) in the Eastern Carpathians. Nordic Journal of Botany 33:633-640. https://doi.org/10.1111/njb.00893

Oh HS. 1971. An anatomical study of Clematis in Korea. Korean Journal of Plant Taxonomy 3:9-16. https://doi.org/10.11110/kjpt.1971.3.1.009

Pedri M, Hussin K, Latiff A. 1991. Anatomi petiole beberapa species daripada family Dipterocarpaceae Malaysia. Prioriti Penyelidikan IRPA, 1991 (1991), pp. 610-617.

Ro KE, Keener CS, McPheron BA. 1997. Molecular phylogenetic study of Ranunculaceae: Utility of the nuclear 26S ribosomal DNA in inferring intrafamilial relationships. Molecular Phylogenetics and Evolution 8:117-127. https://doi.org/10.1006/mpev.1997.0413

Rojo JP. 1987. Petiole anatomy and infrageneric in interspesific relationship Philippines Shorea (Dipterocarpaceae). In Proceedings of the Third Round Table Conference on Dipterocarps, edited by Kostermans, A.J.G.H. pp. 569-601.

Schofield EK. 1968. Petiole anatomy of the Guttiferae and related families. Memoirs of the New York Botanical Garden 18:1-55.

Shi JH, Li LQ. 2003. Leaf epidermal feature in Clematis (Ranunculaceae) with reference to its systematics Acta Botanica Sinica 45:257-268. https://www.jipb.net/CN/Y2003/V45/I3/257

Solereder H. 1908. Systematic Anatomy of the Dicotyledons: A Handbook for Laboratories of Pure and Applied Botany. Vol. I \& II. Oxford: The Clarendon Press.

Talip N, Cutler DF, Puad ASA, Ismail BS, Ruzi AR, Juhari AAA. 2017. Diagnostic and systematic significance of petiole anatomy in the identification of Hopea species (Dipterocarpaceae). South African Journal of Botany 111:111-125. https://doi.org/10.1016/j.sajb.2017.03.008

Tamura M. 1962. Petiolar anatomy in the Ranunculaceae. Science Reports. Osaka University. 11: 1947.

Tamura M. 1987. A classification of genus Clematis. Acta Phytotaxonomica et Geobotanica 38:33-44.

Tamura M. 1993. Ranunculaceae. In: Kubitzki K, Rohwer JG, Bittrich V, eds. The families and genera of vascular plants, Vol. 2. Berlin: Springer-Verlag, 563-583.

Tamura M. 1995. Angiospermae: Ordnung Ranunculales. Fam. Ranunculaceae In: Hiepko P, ed. Die Natürlichen Pflanzenfamilien Vol. 17a(4). Berlin: Duncker \& Humblot, 324-349.

Tobe H. 1974. Morphological studies on the genus Clematis L. I. Pollen grains. The Science Report of the Tohoku University. Fourth Ser (Biology) 37:47-53. 
482

483

484

485

486

487

488

489

490

491

492

493

494

495

496

497

498

499

500

501

502

503

504

505

506

507

508

509

510

511

512

513

514

515

Tobe H. 1979. Morphological studies on the genus Clematis L. IV. Vascular anatomy of the inflorescence axis with some consideration of the evolution of the floral shoot with simple axillary inflorescences. Botanical Magazine Tokyo 92:197-215. https://doi.org/10.1007/BF02488732

Tobe H. 1980a. Morphological studies on the genus Clematis L. V. Vascular anatomy of the calyx region in four-sepaled flowers. Botanical Magazine Tokyo 93:39-54.

Tobe H. 1980b. Morphological studies on the genus Clematis L. VI. Vascular anatomy of the androecial and gynoecial regions of the floral receptacle. Botanical Magazine Tokyo 93:125-133. https://doi.org/10.1007/BF02489119

Tobe H. 1980c. Morphological studies on the genus Clematis L. VII. Reinvestigation of Clematis williamsii A. Gray and proposal of its taxonomic transfer to Clematopsis. Botanical Magazine Tokyo 93: $135-148$.

Tobe H. 1980d. Morphological studies on the genus Clematis L. VIII. Floral and inflorescence anatomy in Clematis patens with eight-sepaled flowers. Botanical Magazine Tokyo 93:253-263.

Wang WT, Li LQ. 2005. A new system of classification of the genus Clematis (Ranunculaceae). Acta Phytotaxonomica Sinica 43:431-488. https://www.jse.ac.cn/EN/Y2005/V43/I5/431

Wang WT, Bartholomew B. 2001. Clematis. In: Wu ZY, Raven P, eds. Flora of China, Vol. 6. Beijing: Science Press; St. Louis MO: Missouri Botanical Garden Press, 333-386.

Wang W, Lu A-M, Ren Y, Endress ME, Chen Z-D. 2009. Phylogeny and classification of Ranunculales: Evidence from four molecular loci and morphological data. Perspectives in Plant Ecology, Evolutions and Systematics. 11:81-110. https://doi.org/10.1016/j.ppees.2009.01.001

Wang W, Liu Y, Yu SX, Gao TG, Chen ZD. 2013. Gymnaconitum, a new genus of Ranunculaceae endemic to the Qinghai-Tibetan Plateau. Taxon 62(4): 713-722. https://doi.org/10.12705/624.10

Wang W, Li HL, Xiang XG, Chen ZD. 2014. Revisiting the phylogeny of Ranunculeae: implications for divergence time estimation and historical biogeography. Journal of Systematics and Evolution 52: 551-565. https://doi.org/10.1111/jse.12101

Worsdell WC. 1908. A study of the vascular system in certain orders of the Ranales. Annals of Botany 22:651-682. https://www.jstor.org/stable/43236629

Xie L, Wen J, Li LQ. 2011. Phylogenetic analyses of Clematis (Ranunculaceae) based on sequences of nuclear ribosomal ITS and three plastid regions. Systematic Botany 36:907-92. https://doi.org/10.1600/036364411X604921

Xie L, Li LQ. 2012. Variation of pollen morphology, and its implications in the phylogeny of Clematis (Ranunculaceae). Plant Systematics and Evolution 298:1437-1453. https://doi.org/10.1007/s00606012-0648-y

Yang TY, Moore DM. 1999. A revision of the Viorna group of species (section Viorna sensu Prantl) in 
516 the genus Clematis (Ranunculaceae). Systematics and Geography of Plants 68:281-303.

$517 \quad$ https://doi.org/10.2307/3668608

518 Yano Y. 1993. Pollen grain morphology in Clematis (Ranunculaceae). Clematis 1993:42-43.

519 Zhai W, Duan X, Zhang R, Guo C, Li Lin, Xu G, Shan H, Kong H, Ren Y. 2019. Chloroplast

520 genomic data provide new and robust insights into the phylogeny and evolution of the Ranunculaceae.

521 Molecular Phylogenetics and Evolution 135: 12-21. https://doi.org/10.1016/j.ympev.2019.02.024

522 Zhang YL, He SY. 1991. Chromosome studies on 7 species of Clematis in China. Journal of Wuhan 523 Botanical Research 9:107-113. 
Figure 1

Petiole of Clematis under stereomicroscope.

A. C. apiifolia. B. C. brevicaudata. C. C. trichotoma. D. C. taeguensis. E. C. hexapetala. F. C. terniflora. G. C. terniflora var. mandshurica. H. C. heraclefolia. I. C. urticifolia. J. C. takedana. K. C. patens. L. C. brachyura. M. C. serratifolia. N. C. fusca var. fusca. O. C. fusca var. flabellata. P. C. fusca var. violacea. Q. C. calcicola. R. C. koreana. S. C. ochotensis. Scale bars: $1 \mathrm{~mm}$. 

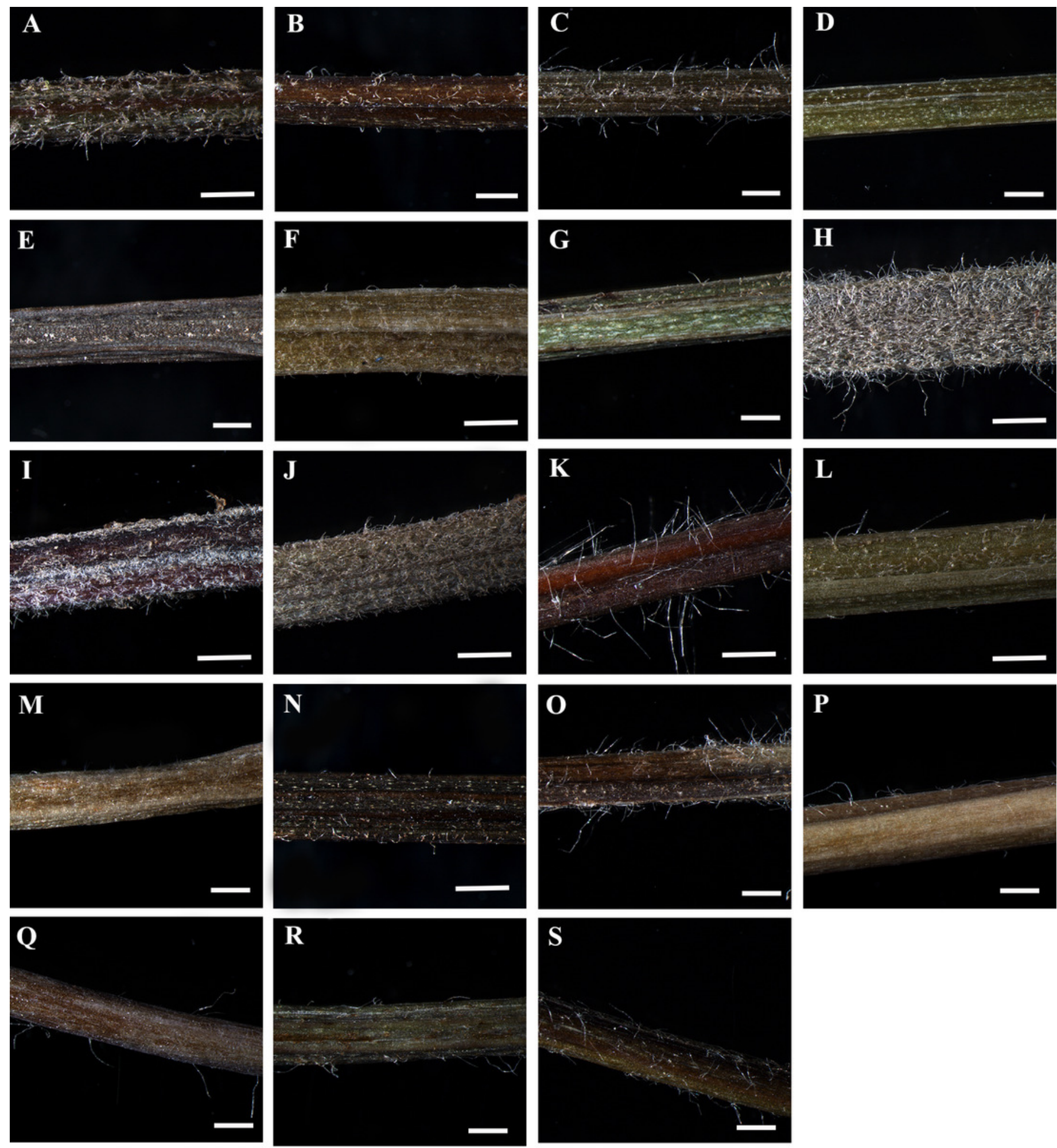

$\mathbf{R}$

S

$\mathbf{P}$

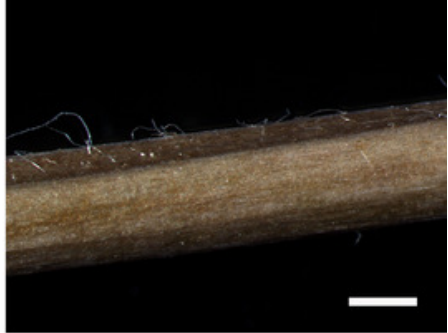


Figure 2

Scanning electron micrograph of petiole of Clematis.

A-B. C. heraclefolia. C-D. C. taeguensis. E-F. C. patens. G-H. C. brevicaudata. I-J. C. fusca var. violacea. Abbreviations: gt, glandular trichome. Scale bar: $200 \mu \mathrm{m}$ (A, C, E, G, I), $100 \mu \mathrm{m}$ (B, $D, F, H, J)$. 

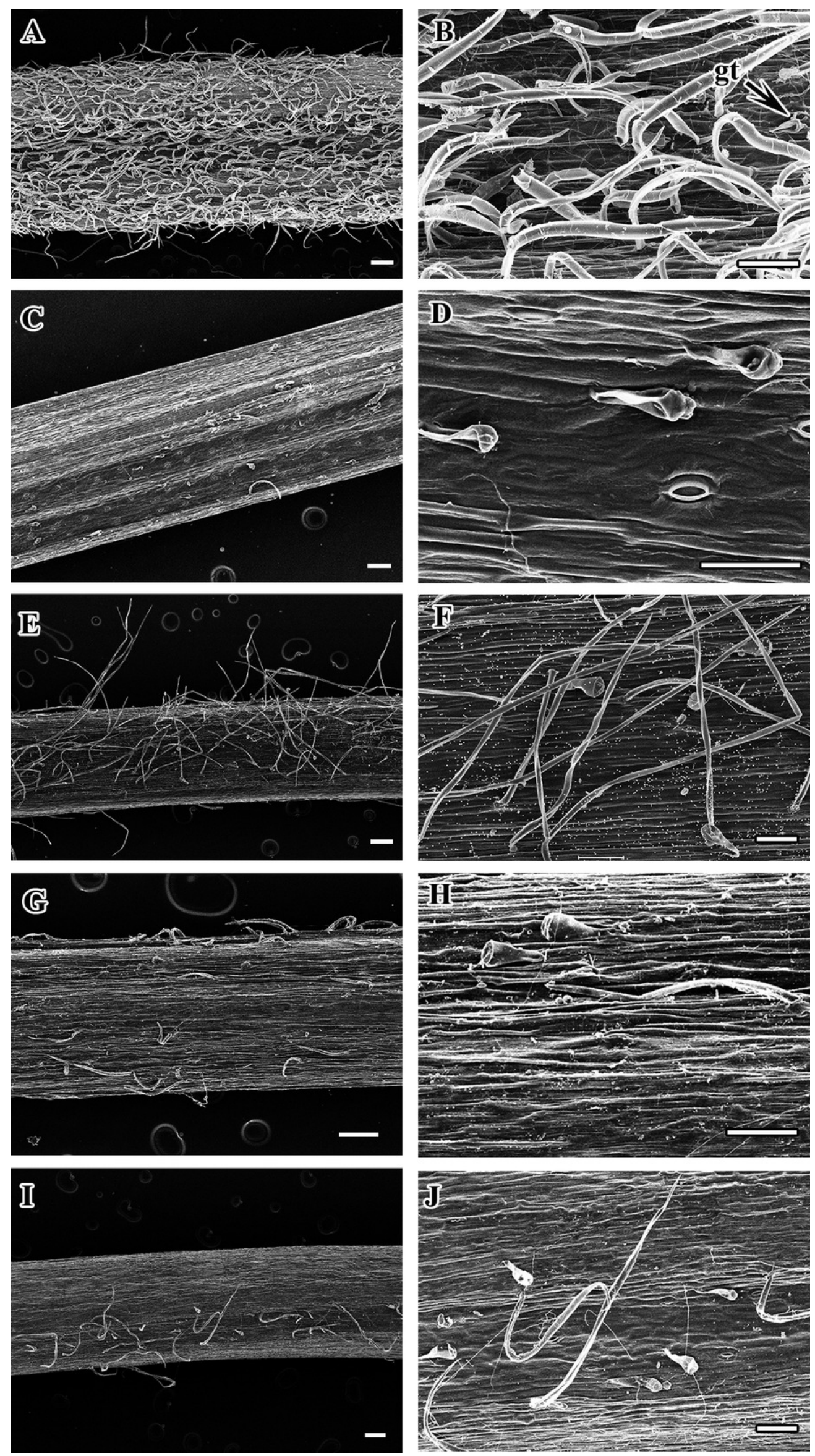

PeerJ reviewing PDF | (2020:12:56114:2:0:CHECK 7 May 2021) 
Figure 3

Cross section of petiole of Clematis.

A-B. C. apiifolia. C-D. C. brevicaudata. E-F. C. trichotoma. G-H. C. taeguensis I-J. C.

hexapetala. K-L. C. terniflora. Abbreviations: co, collenchyma; cu, cuticle; ep, epidermis; ph, phloem; phf, phloem fiber; s, stomata; $x y$, xylem. Scale bars: $50 \mu \mathrm{m}(B, D, J), 75 \mu \mathrm{m}(F, H, L)$, $100 \mu \mathrm{m}(\mathrm{A}, \mathrm{C}, \mathrm{I}), 200 \mu \mathrm{m}(\mathrm{E}, \mathrm{G}, \mathrm{K})$. 
A
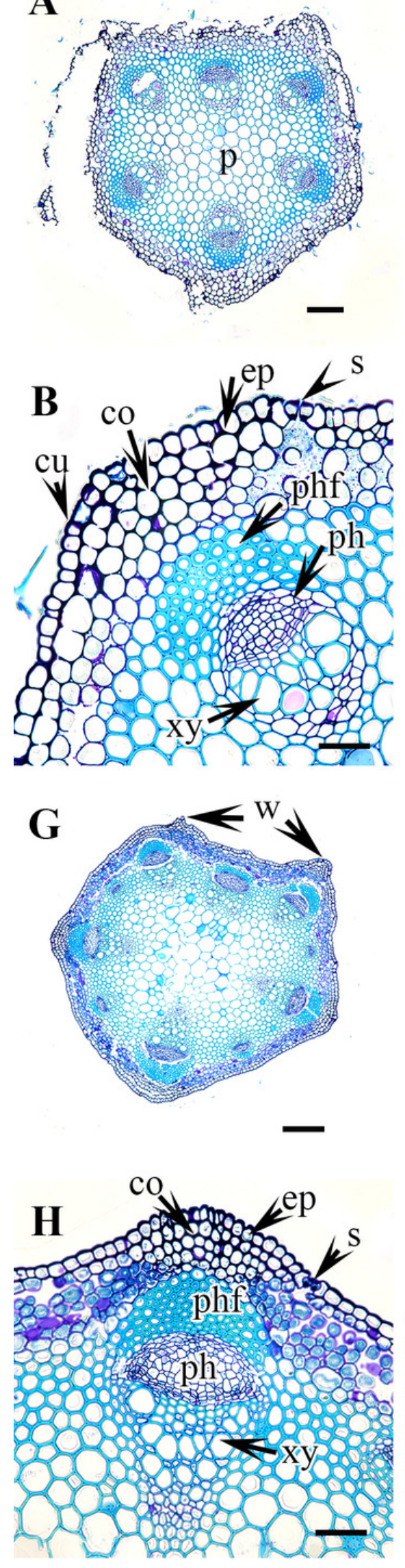
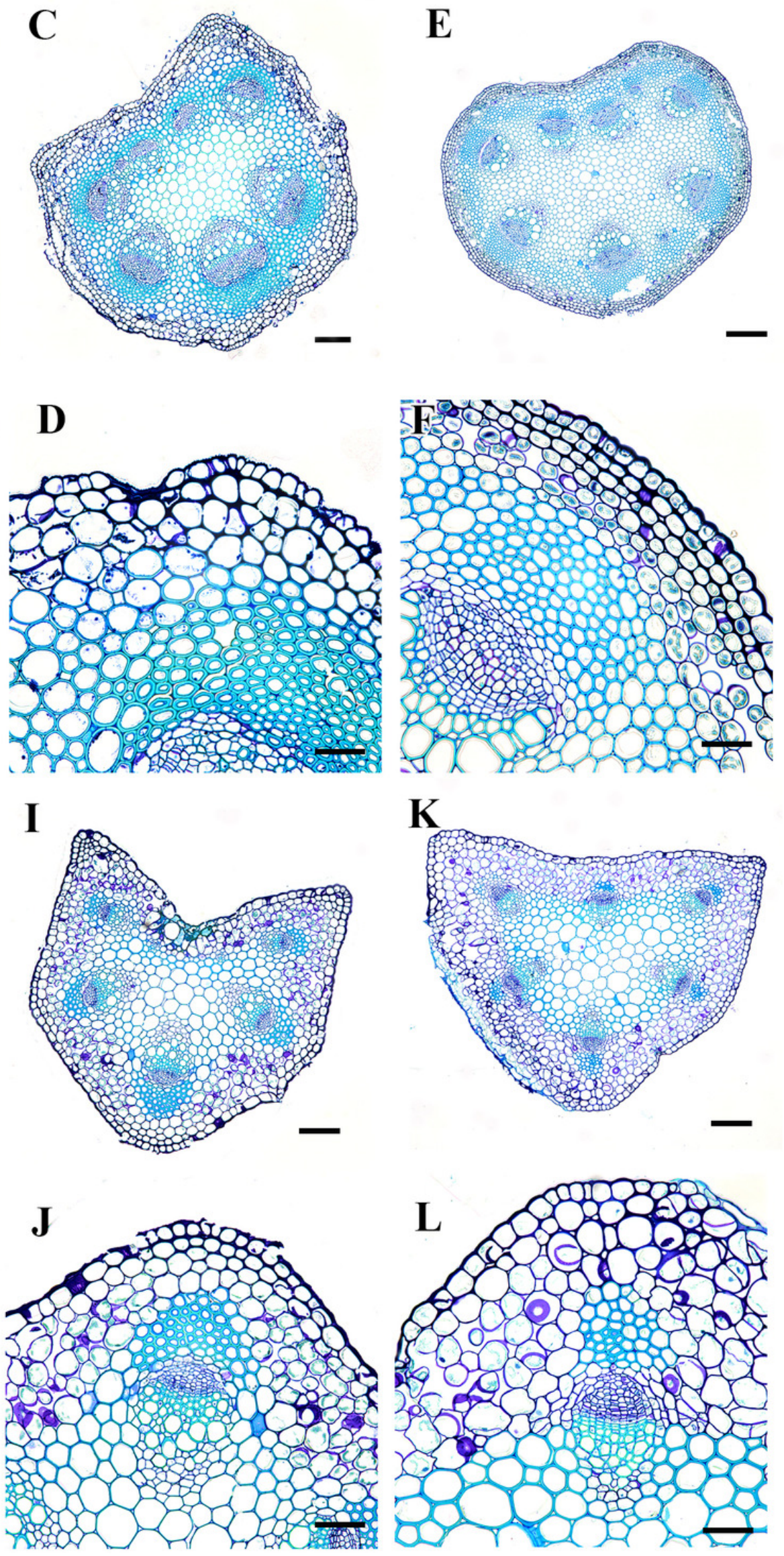
Figure 4

Cross section of petiole of Clematis.

A-B. C. terniflora var. mandshurica. C-D. C. urticifolia. E-F. C. heraclefolia. G-H. C. takedana. IJ. C. patens. K-L. C. brachyura. Abbreviations: co, collenchyma; cu, cuticle; ep, epidermis; ph, phloem; phf, phloem fiber; s, stomata; sc, sclerenchyma; xy, xylem. Scale bars: Scale bars: $50 \mu \mathrm{m}(\mathrm{B}, \mathrm{J}, \mathrm{L}), 100 \mu \mathrm{m}(\mathrm{A}, \mathrm{I}, \mathrm{K}, \mathrm{F}, \mathrm{D}, \mathrm{H}), 500 \mu \mathrm{m}(\mathrm{C}, \mathrm{E}, \mathrm{G})$. 

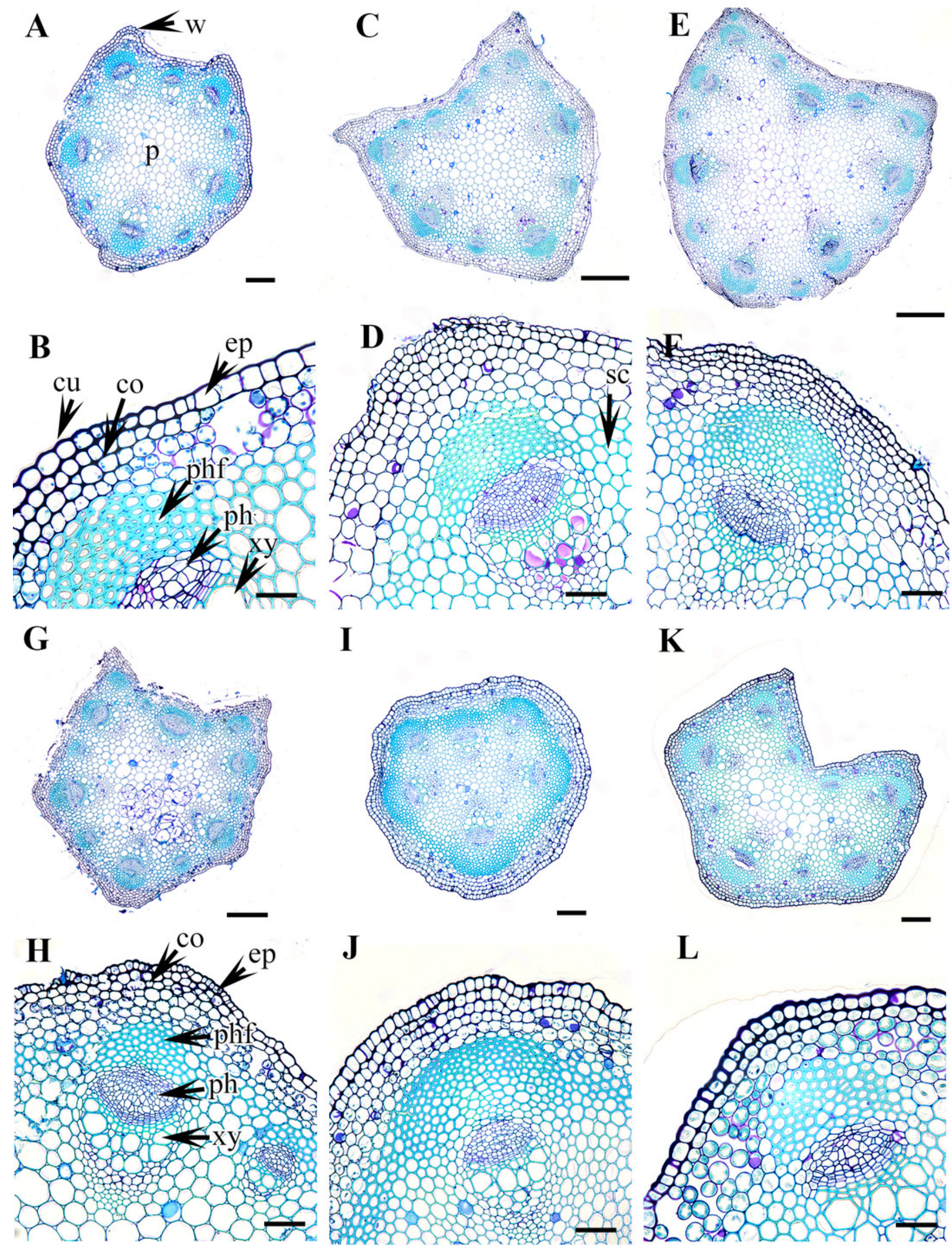

$\mathbf{J}$
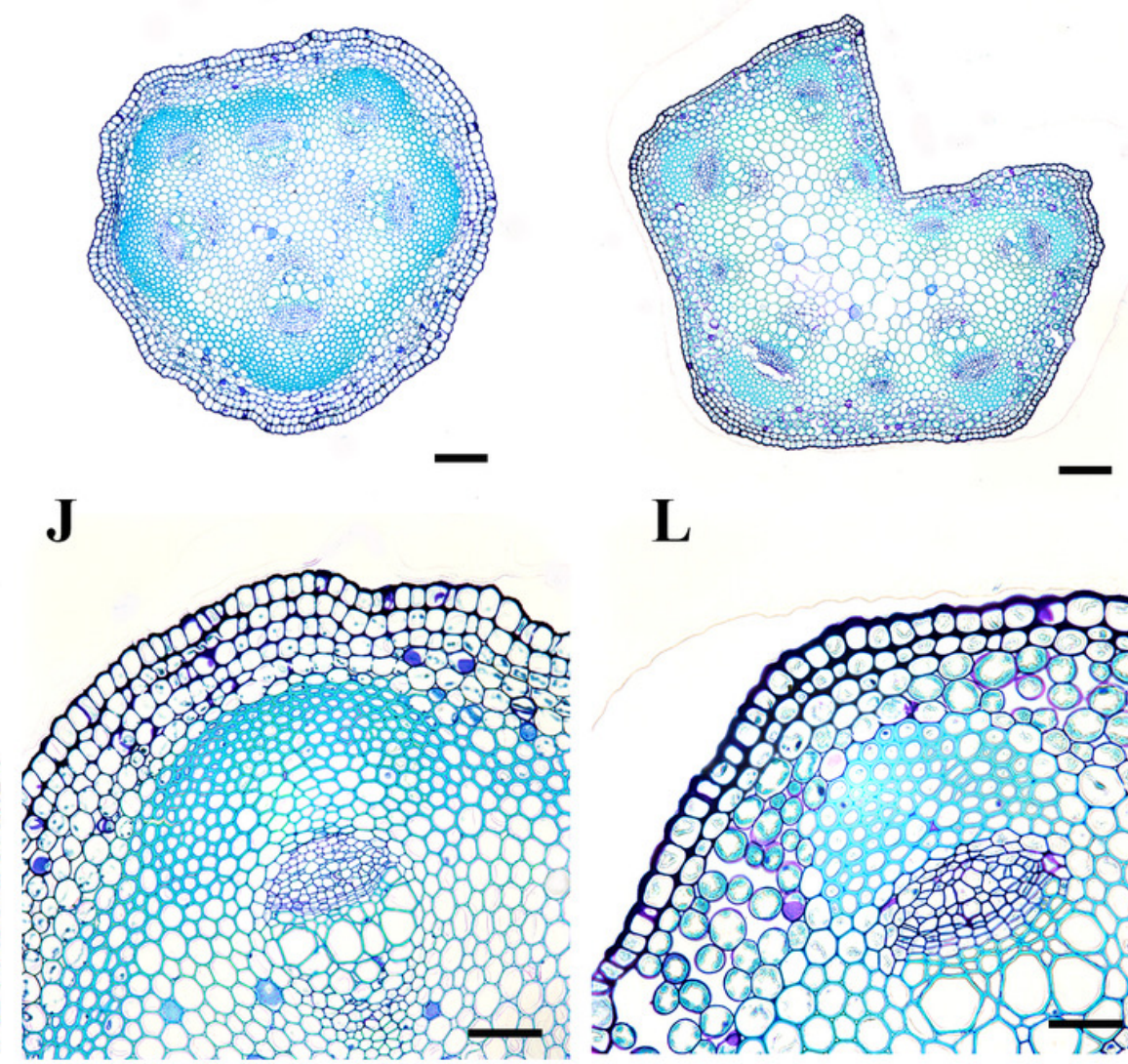

L

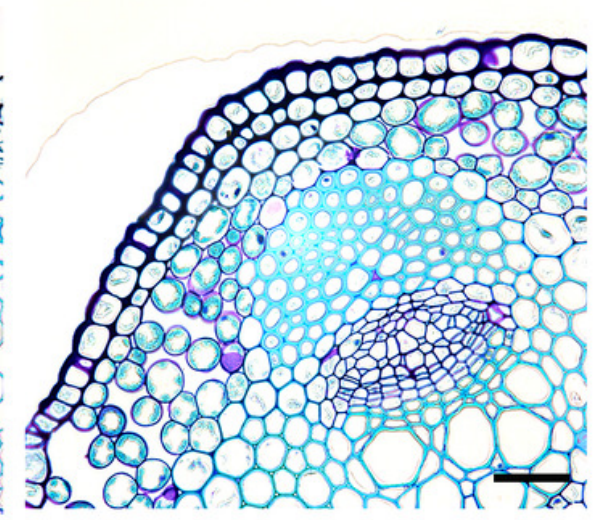


Figure 5

Cross section of petiole of Clematis.

A-B. C. serratifolia. C-D. C. fusca var. fusca. E-F. C. fusca var. flabellata. G-H. C. fusca var. violacea. I-J. C. calcicola. K-L C. koreana. Abbreviations: co, collenchyma; cu, cuticle; ep, epidermis; ph, phloem; phf, phloem fiber; s, stomata; $x y$, xylem. Scale bars: $75 \mu \mathrm{m}(B, D, F$, $H, J, L), 200 \mu m(A, C, E, G, I, K)$. 
A
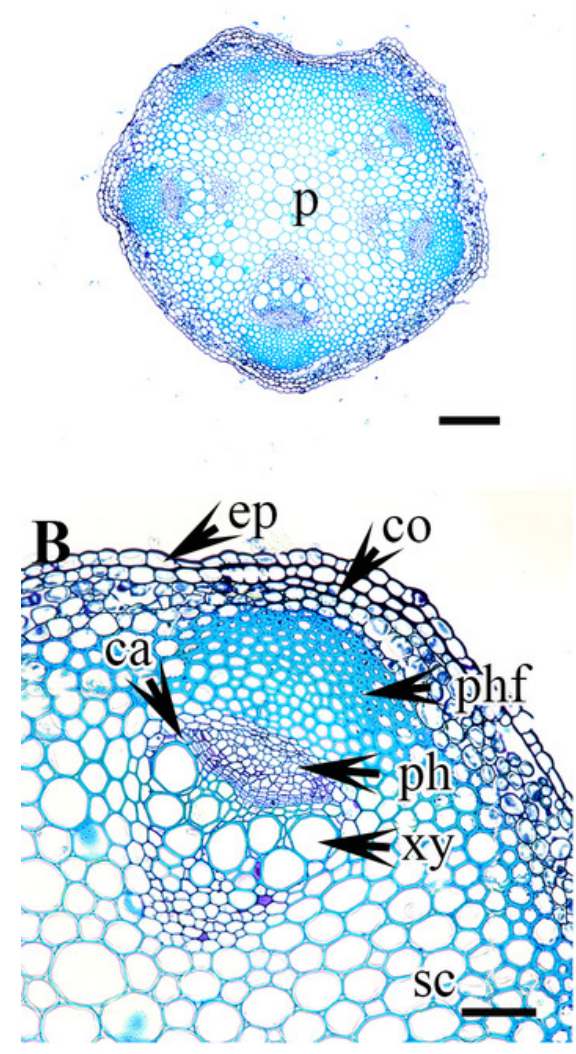

G

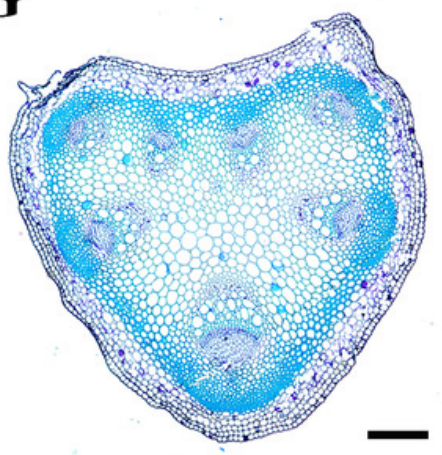

C
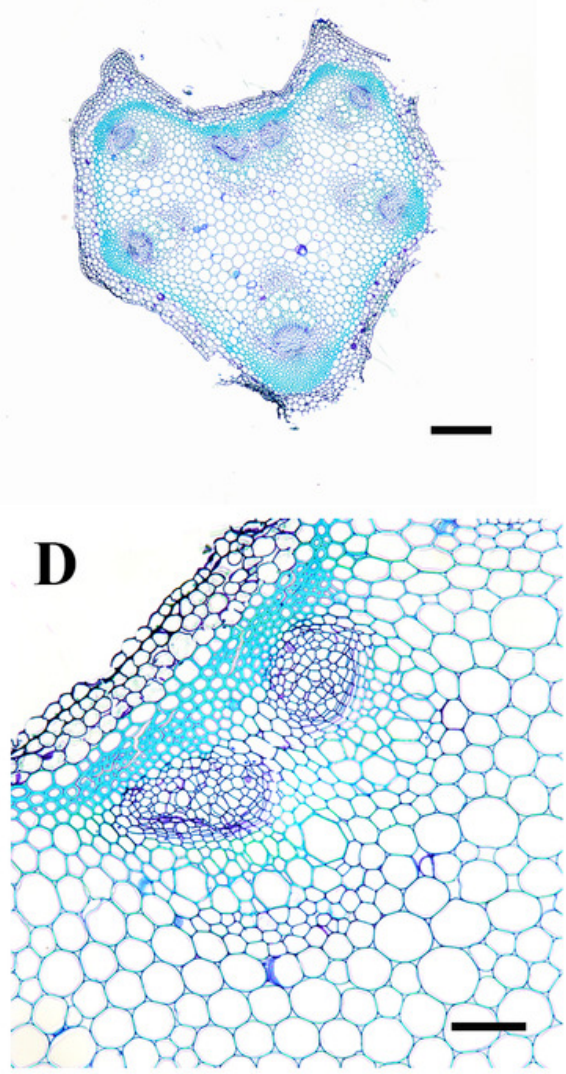

I

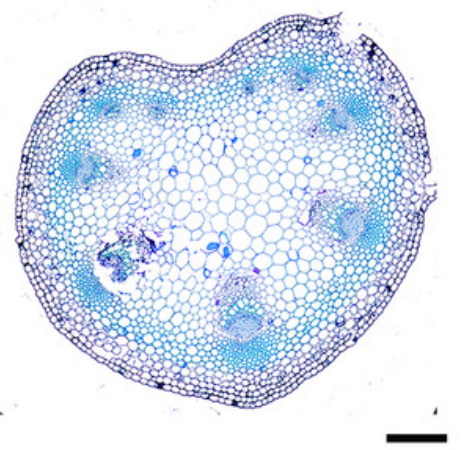

E
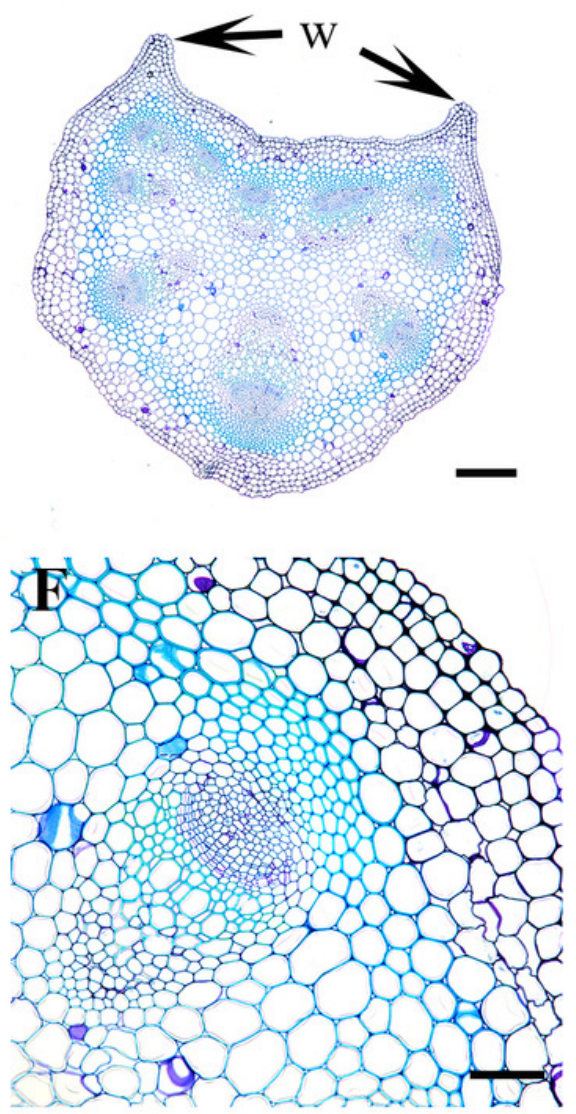

K

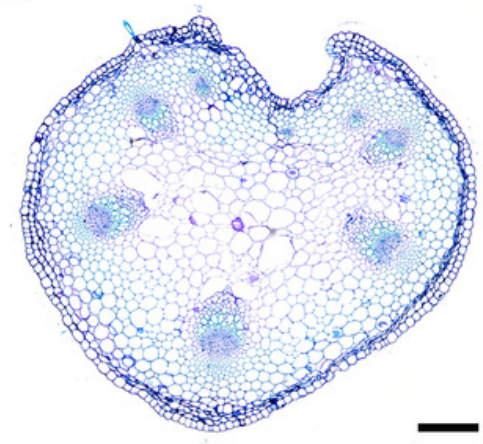

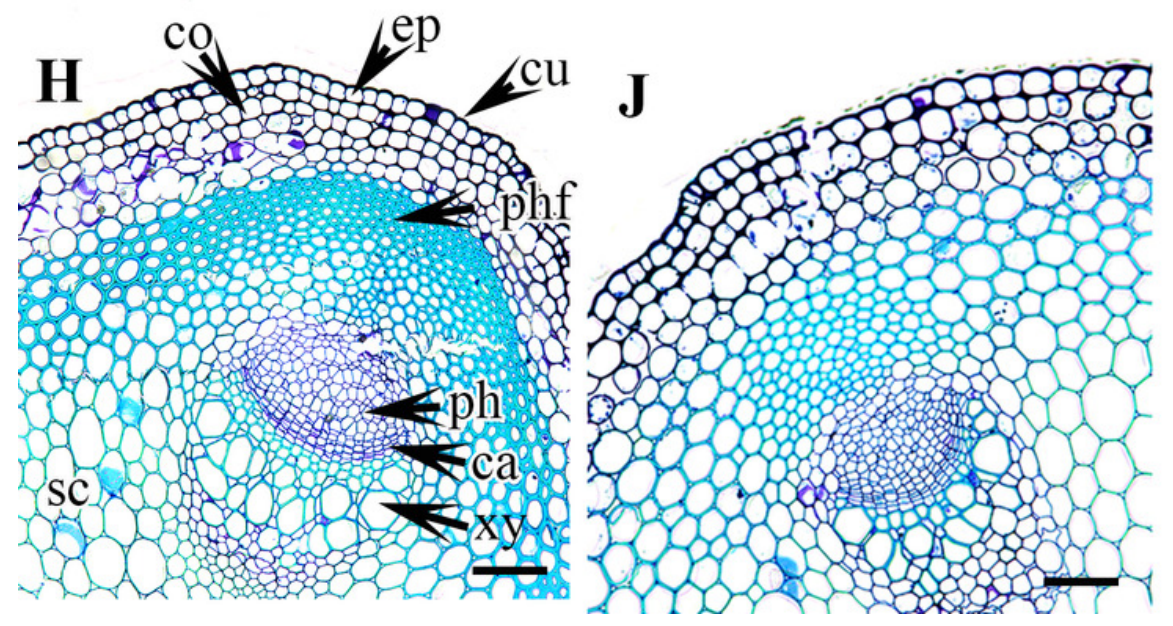

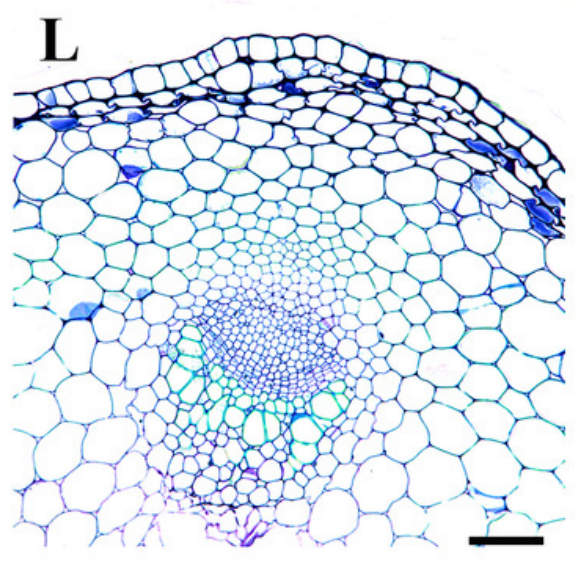


Figure 6

Cross section of petiole of Clematis.

A-B. C. ochotensis. Abbreviations: co, collenchyma; cu, cuticle; ep, epidermis; ph, phloem; phf, phloem fiber; s, stomata; xy, xylem. Scale bars: $75 \mu \mathrm{m}$ (B), $200 \mu \mathrm{m}(\mathrm{A})$. 
A
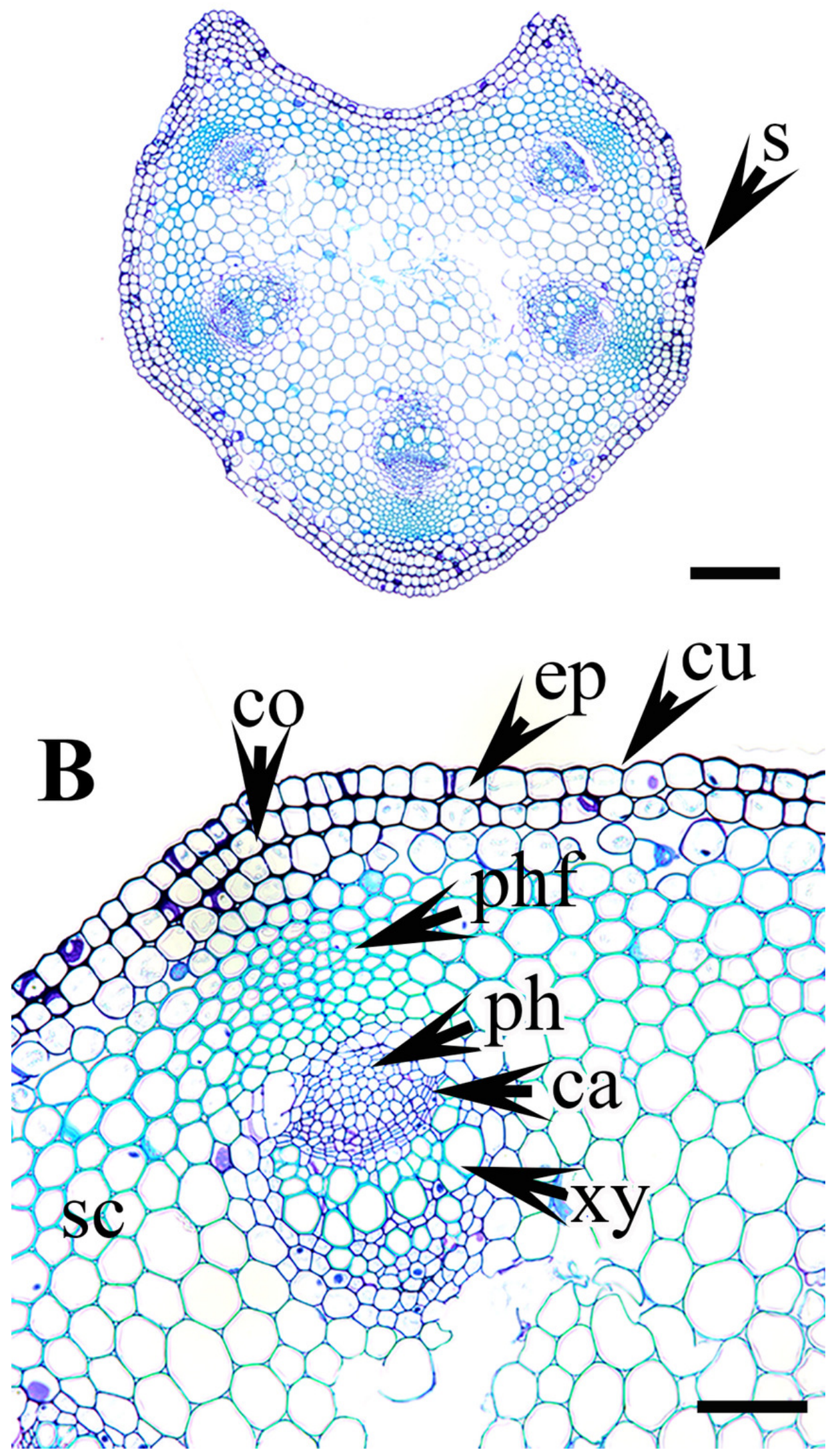

Peer) reviewing PDF | (2020:12:56114:2:0:CHECK 7 May 2021) 


\section{Figure 7}

Principal component analysis (PCA) of 13 petiole characters of Clematis taxa.

PS, petiole surface; $\Pi$, trichome type; GT, glandular trichome; TA, trichome abundance; PO, petiole outline in cross-section; UW, upper surface wings; UG, upper surface groove; PF, phloem fiber cap; SC, interfascicular sclerenchyma; MV, major vascular bundles; IV, interfascicular vascular bundle; VB, total vascular bundle; VG, vascular bundles in the groove. Different colour represents different sections of the genus.

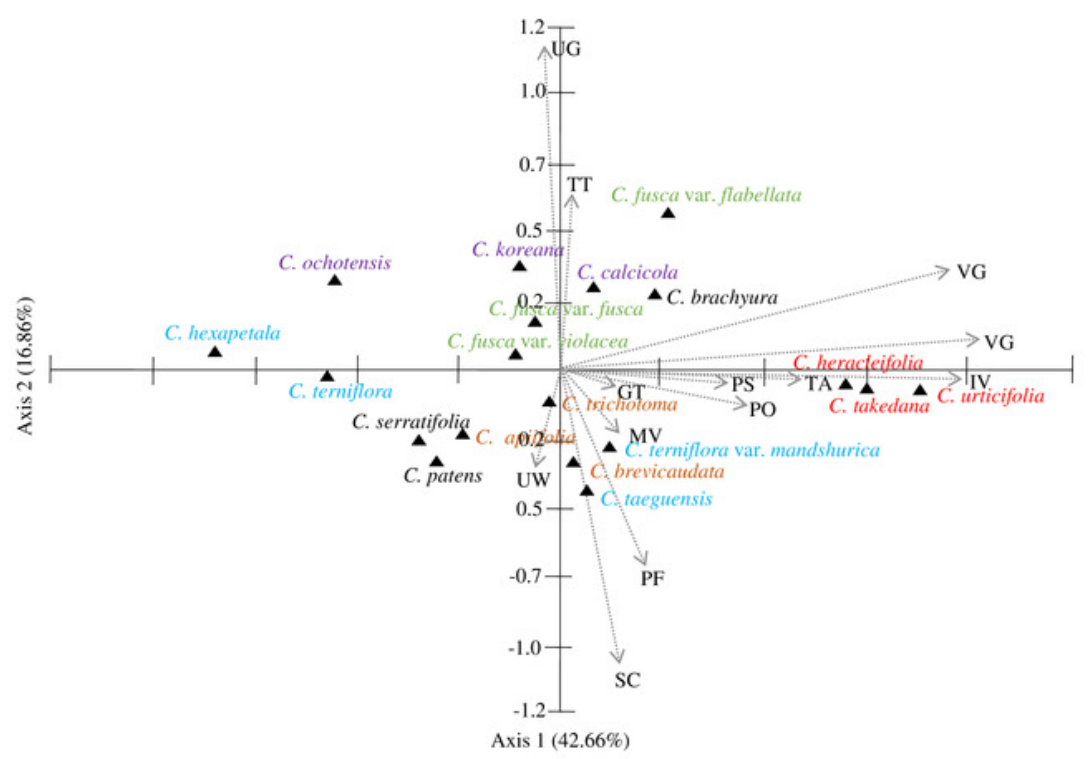


Figure 8

UPGMA cluster analysis based on petiole characters of Clematis taxa. Different colours represents different sections of the genus.

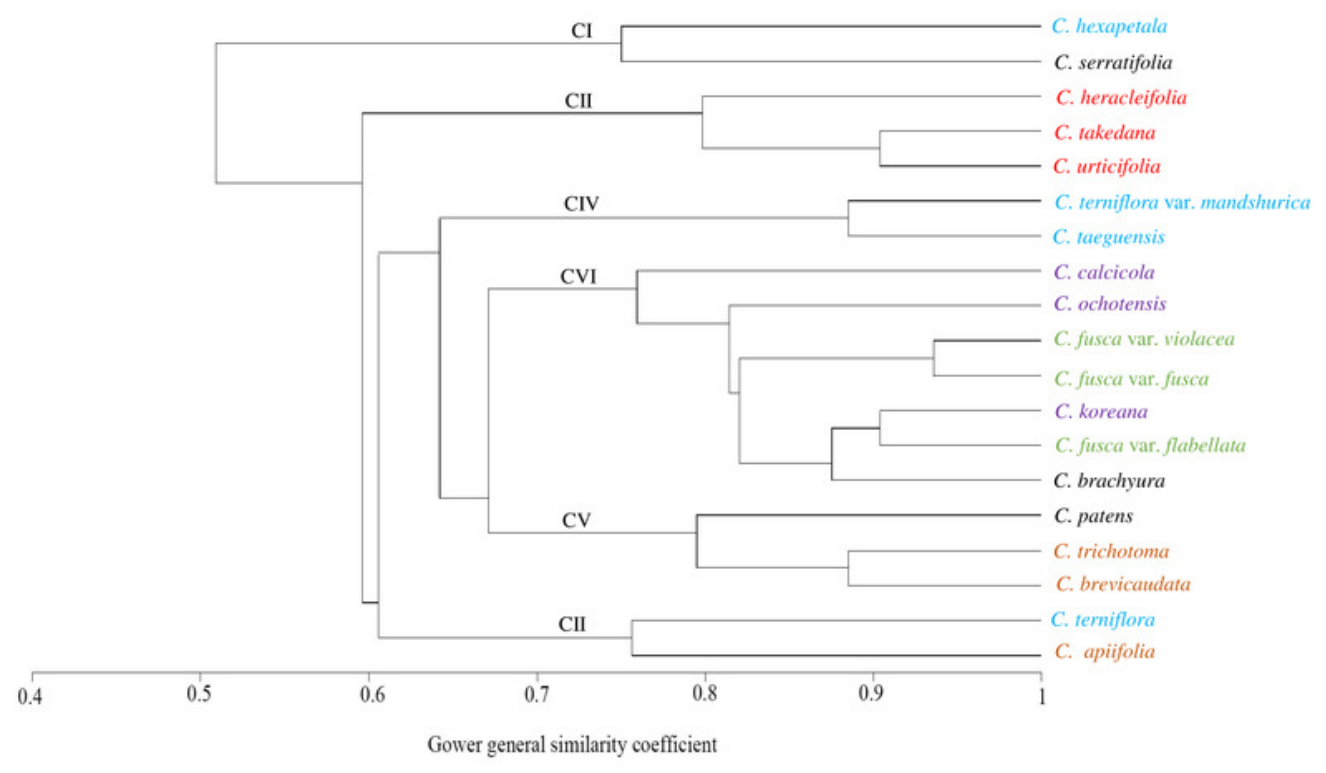




\section{Table 1 (on next page)}

Name of taxa with voucher number, collection information, and different classifications. 
1 Table 1. Name of taxa with voucher number and collection information with different classifications.

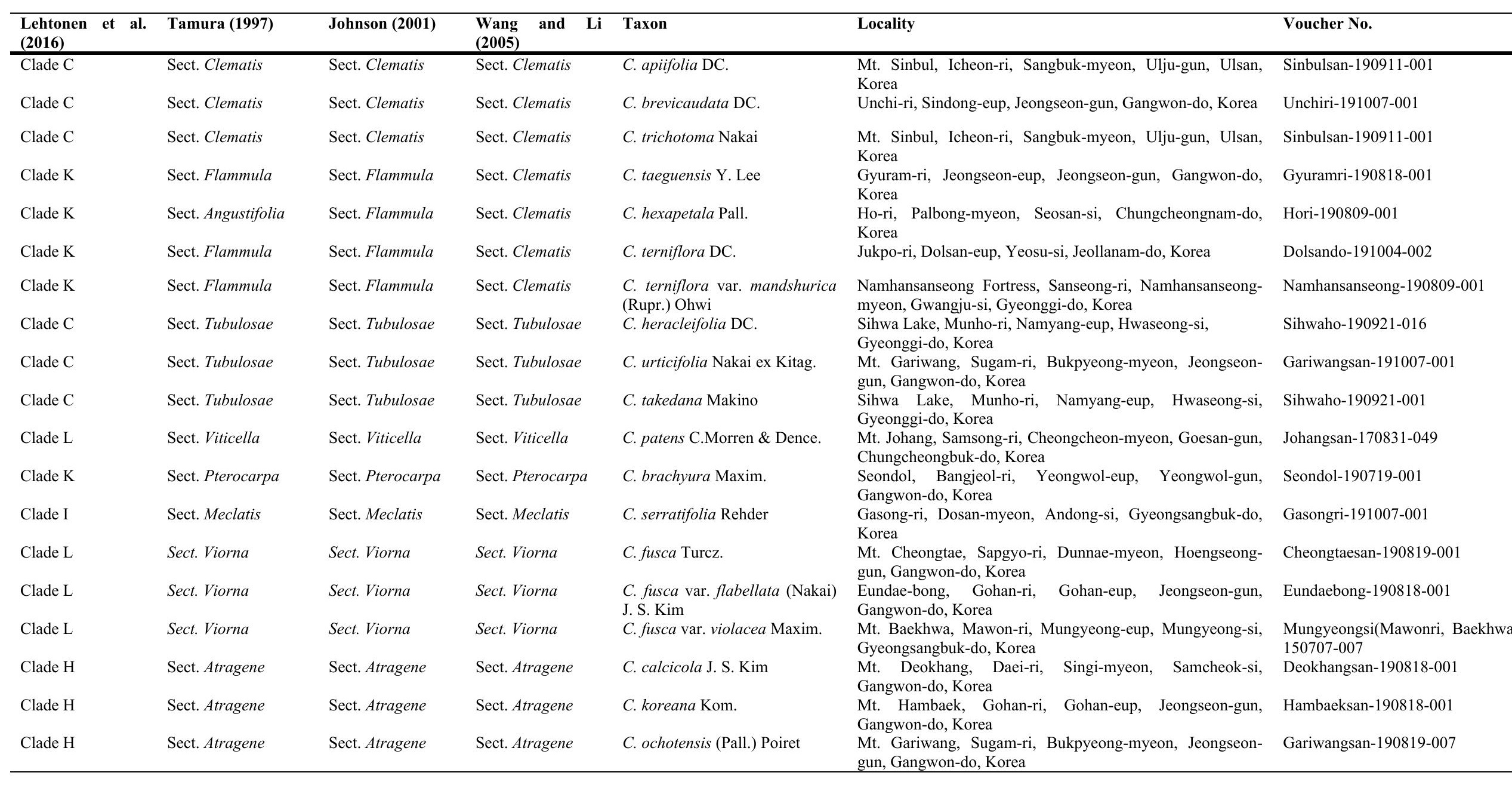




\section{Table 2 (on next page)}

Morphological and anatomical features of petiole of Clematis species.

Abbreviations: MVB, major vascular bundles; IVB, interfascicular vascular bundle; TVB, total vascular bundle; VBG, vascular bundles in groove. 
1 Table 2. Morphological and anatomical features of petiole of Clematis species.

\begin{tabular}{|c|c|c|c|c|c|c|}
\hline Taxon & Petiole surface & Non-glandular trichomes & $\begin{array}{l}\text { Glandular } \\
\text { trichomes }\end{array}$ & $\begin{array}{l}\text { Trichome } \\
\text { abundance }\end{array}$ & $\begin{array}{l}\text { Petiole outline in cross } \\
\text { section }\end{array}$ & Upper surface wings \\
\hline C. apiifolia & Villous & Unicate & Present & High & Pentagonal & Inconspicuous/conspicuous \\
\hline C. brevicaudata & Villous & Unicate & Present & Medium & U-shaped & Inconspicuous \\
\hline C. trichotoma & Pilose & Flagelliform & Present & Medium & U-shaped & Inconspicuous \\
\hline C. taeguensis & Subglabrous/pilose & Flagelliform & Present & Low & Pentagonal & Conspicuous \\
\hline C. hexapetala & Glabrous & Absent & Absent & None & U-shaped /pentagonal & Conspicuous \\
\hline C. terniflora & Pilose & Flagelliform & Present & Low & Semi-circular/ U-shaped & Inconspicuous/conspicuous \\
\hline $\begin{array}{l}\text { C. terniflora } \text { var. } \\
\text { mandshurica }\end{array}$ & Pilose & Flagelliform & Present & Low & Pentagonal & Conspicuous \\
\hline C. urticifolia & Villous & Unicate & Present & High & Pentagonal & Conspicuous \\
\hline C. heracleifolia & Villous & Unicate & Present & High & U-shaped & Inconspicuous \\
\hline C. takedana & Villous & Unicate & Present & High & Pentagonal & Conspicuous \\
\hline C. patens & Pilose & Flagelliform & Present & Medium & U-shaped & Inconspicuous \\
\hline C. brachyura & Pilose & Flagelliform & Present & $\begin{array}{l}\text { Medium (in upper } \\
\text { surface groove) }\end{array}$ & Pentagonal & Conspicuous \\
\hline C. serratifolia & Subglabrous/pilose & Flagelliform & Absent & Low & U-shaped /pentagonal & Conspicuous \\
\hline C. fusca var. fusca & Pilose & Flagelliform & Present & Low & Pentagonal & Conspicuous \\
\hline C. fusca var. flabellata & Pilose & Flagelliform & Present & Medium & U-shaped & Conspicuous \\
\hline C. fusca var. violacea & Pilose & Flagelliform (in groove) & Present & Low & U-shaped & Conspicuous \\
\hline C. calcicola & Subglabrous/pilose & Flagelliform & Absent & Low & U-shaped & Inconspicuous/conspicuous \\
\hline C. koreana & Pilose & Flagelliform & Present & Medium & U-shaped & Conspicuous \\
\hline C. ochotensis & Pilose & Flagelliform & Present & Medium & U-shaped & Conspicuous \\
\hline
\end{tabular}




\begin{tabular}{|c|c|c|c|c|c|c|c|}
\hline Taxon & Upper surface groove & Phloem fiber cap & $\begin{array}{l}\text { Interfascicular } \\
\text { sclerenchyma }\end{array}$ & MVB & IVB & TVB & BVG \\
\hline C. apiifolia & Flattened/Sub-flattened & Medium, 5-10 layers & $<5$ layers & 6 & 0 & 6 & 1 \\
\hline C. brevicaudata & Sub flattened & Large, $>10$ layers & $>10$ layers & 5 & 2 to 3 & 7 to 8 & 2 \\
\hline C. trichotoma & Sub flattened & Large, $>10$ layers & 5-10 layers & 5 & 2 & 7 & 2 \\
\hline C. taeguensis & Sub flattened & Large, $>10$ layers & $>10$ layers & 6 & 4 & 10 & 1 \\
\hline C. hexapetala & V-shaped & Medium, 5-10 layers & $<5$ layers & 5 & 0 & 5 & 0 \\
\hline C. terniflora & Flattened/Sub flattened & Small, $<5$ layers & $<5$ layers & 6 & 0 & 6 & 1 \\
\hline C. terniflora var. mandshurica & Sub flattened & Large, $>10$ layers & $>10$ layers & 6 & 4 & 10 & 1 \\
\hline C. urticifolia & Sub flattened & Large, $>10$ layers & 5-10 layers & 5 & 8 & 13 & 4 \\
\hline C. heracleifolia & Sub flattened & Large, $>10$ layers & $<5$ layers & 6 & 8 & 14 & 3 \\
\hline C. takedana & Sub flattened & Medium, 5-10 layers & 5-10 layers & 6 & 7 & 13 & 3 \\
\hline C. patens & Flattened & Medium, 5-10 layers & $>10$ layers & 4 & 2 & 6 & 1 \\
\hline C. brachyura & V-shaped & Medium, 5-10 layers & $<5$ layers & 5 & 4 & 9 & 2 \\
\hline C. serratifolia & Sub flattened/U-shaped & Large, $>10$ layers & 5-10 layers & 5 & 3 & 8 & 1 \\
\hline C. fusca var. fusca & U-shaped & Large, $>10$ layers & $<5$ layers & 5 & 2 & 7 & 2 \\
\hline C. fusca var. flabellata & U-shaped & Small, $<5$ layers & $<5$ layers & 5 & 5 & 10 & 3 \\
\hline C. fusca var. violacea & Sub flattened & Large, $>10$ layers & $<5$ layers & 5 & 2 & 7 & 2 \\
\hline C. calcicola & Sub flattened/U-shaped & Medium, 5-10 layers & $<5$ layers & 5 & 4 & 9 & 2 \\
\hline C. koreana & V-shaped & Small, $<5$ layers & $<5$ layers & 5 & 3 & 8 & 2 \\
\hline C. ochotensis & U-shaped & Medium, 5-10 layers & $<5$ layers & 5 & 0 & 5 & 0 \\
\hline
\end{tabular}

Abbreviations: MVB, major vascular bundles; IVB, interfascicular vascular bundle; TVB, total vascular bundle; VBG, vascular bundles in groove. 